\title{
Exercise tissue Doppler echocardiography with strain rate imaging in healthy young individuals: feasibility, normal values and reproducibility
}

\author{
Björn Goebel · Raoul Arnold · Eric Koletzki • \\ Herbert E. Ulmer · Joachim Eichhorn • \\ Martin Borggrefe · Hans R. Figulla \\ Tudor C. Poerner
}

Published online: 27 September 2006

(C) Springer Science+Business Media B.V. 2006

\section{Erratum to: Int J Cardiovasc Imaging DOI 10.1007/s10554-006-9130-7}

In the original publication of this article, the following information was missing:

The authors B. Goebel and R. Arnold contributed equally to this work.

The online version of the original article can be found at http://www.dx.doi.org/10.1007/s10554-006-9130-7

B. Goebel · H. R. Figulla · T. C. Poerner $(\bowtie)$ Klinik für Innere Medizin I, Universitätsklinikum Jena, Friedrich-Schiller-Universität Jena, ErlangerAllee 101, D-07743 Jena, Germany e-mail: poerner@t-online.de

E. Koletzki · M. Borggrefe · B. Goebel ·

T. C. Poerner

I. Med. Klinik, Universitätsklinikum Mannheim, Theodor-Kutzer-Ufer 1-3, D-68135 Mannheim,

Germany

R. Arnold · H. E. Ulmer · J. Eichhorn Department of Pediatric Cardiology, Universitätskinderklinik Heidelberg, Neuenheimer Feld 120, D-69120 Heidelberg, Germany

R. Arnold

Department of Pediatric Cardiology,

Universitätskinderklinik Freiburg, Mathildenstraße 1,

D-79106 Freiburg, Germany 